\title{
An Effective use of Visual Aids for Teaching Computer Aided Manufacturing (CAM) Laboratory - A case Study
}

\author{
Mukund V. Kavade \\ Department of Mechanical Engineering, Rajarambapu Institute of Technology, Rajaramnagar, Sakharale, Maharashtra, India. \\ mukund.kavade@ ritindia.edu
}

\begin{abstract}
This paper presents use of visual aid to improve the teaching of skill based laboratory course. Teaching of a laboratory course where knowledge and skills are imparted to the students through hands on is bit different from other courses. CAM Laboratory is one of such courses. In $\mathrm{CAD} / \mathrm{CAM} / \mathrm{CAE}$ and similar laboratory courses, at the start of every new experiment course instructor first explains the related theory and then demonstrates the various software tools to be used for the experiment using suitable software application. Students will then complete the experiments using the knowledge and skills (software tools) taught by the course instructor. It is observed that at the beginning of every new experiment students are stuck with some problems and could not continue the experiment. In such case students calls the faculty for the guidance. Many times situation arises when numbers of students are stuck with problem and need assistance of the course instructor to solve the problem. Course instructor can attend only one student at a time and other students have to wait for their turn to come. This problem can be solved by using visual aids like video clips. When teacher is demonstrating various software tools to students he/she can capture the screen activities in a video clip,. This video clip is then shared with students. When students are practicing these tools and stuck with some problem they will refer the video clip and can solve problem on their own. No need for the teacher to come to guide them in solving the problems. I have taught CAM Laboratory course to the M. Tech. Mechanical (Production engineering) students in last semester. I realised at the middle of semester that many students are facing the problems at the beginning of
\end{abstract}

\footnotetext{
Mukund V. Kavade

Department of Mechanical Engineering

Rajarambapu Institute of technology, Maharashtra

- 415414, India

Mukund.kavade@ritindia.edu
}

new semester. I started capturing the screen activities in a video clip while I was demonstrating the software tools to the students. These clips were then shared with students. Students used these clips to solve the problem on their own. This practice resulted in i) less number of calls from the students to solve their problems ii) Students could complete the experiments in much lesser time than they used to earlier iii) performance grades of the students improved as they could submit the experiments in time.

Keywords: CAD/CAM/CAE, Siemens NX CAD/CAM software, Active learning

\section{Introduction}

Research in education has proved that you never teach anyone how to do anything by telling them how to do it. Rather, you teach them by showing them how, and then having them try it themselves and giving them corrective feedback. As we cannot teach someone how to ride a bicycle or how to drive the car, same is the case with designing a component, generating a tool path for machining of the component etc. We have to use active learning techniques for this.

The only way skill is developed - skiing, cooking, writing, critical thinking, designing a component - is practice. Why not help students develop some skills during the contact hours by giving them some practice in the tasks they will later be asked to perform (Felder and Brent, 2003). Incorporating visual tools in your session helps students understand the concept better and their imaginations thrive and grow (D. Kalyani and K. Rajasekaran (2018). Innovative learning methods suggested by these authors are:

i) Crossover learning - learning in informal settings such as museum and after school clubs.

ii) Learning through argumentation students can advance their understanding by arguing in ways similar to professionals. 
iii)

Incidental learning - Incidental learning is unplanned or unintentional learning. It may occur while carrying out an activity that is seemingly unrelated to what is learned.

iv) Learning by doing - Engaging students with authentic scientific tools and practices such as designing, modeling, constructing. This improves conceptual understanding, and increase motivation.

v) Embodied learning - Embodied learning involves self-awareness of the body interacting with a real or simulated world to support the learning process. When learning a new sport, Executive summary 5 physical movements is an obvious part of the learning process. In embodied learning, the aim is that mind and body work together so that physical feedback and actions reinforce the learning process.

Authors Ujjwal Patil et. al. in their paper "Activity based teaching learning (ABTL): An experience" have shown enhancement in attainment of course outcomes through ABTL compared to conventional teaching learning process (Ujjwala Patil et. al., 2018).

\section{Visual Aids for Teaching Skill Based Laboratory Course}

In skill based laboratory courses using software students gain knowledge and skills through hands on practices. In such practices, students go through the initial barrier of getting accustomed to the software tools. They need guidance of the faculty frequently. Visual tools like video clips on how to use various software tools comes handy in such situations. Whenever student face problem he/she can refer the visual aid and solve the problem on their own.

Visual aids have been used in teaching of skill based laboratory course "Computer Aided Manufacturing Laboratory" for first year students of M. Tech. Mechanical (Production Engineering). This laboratory course was taught using Siemens NX CAD/CAM software. Following are the course outcomes:

i) Develop sketches using suitable CAD/CAM software

ii) Develop part models using suitable CAD/CAM software

iii) Generate tool path and part program for plain milling operation.

iv) Generate tool path and part program for contour milling operation.

v) Generate tool path and part program for turning operation.
These five course outcomes were achieved through eight exercises/experiments. During first four experiments it was realised that at the start of the new experiments students are facing lots of problems regarding use of software tools. In Siemens NX CAD/CAM software a tool has been provided which can be used to capture the screen activities in a video clip. Fifth experiments onwards this software facility was used to capture the screen activities in a video clip while faculty was demonstrating the experiments to the students. These video clips were then shared with students. Whenever students stuck with the problems they refer the video clip and solve the problem without seeking the guidance of the faculty. Fig.1, 2 and 3 shows the stills captured from such video clips.

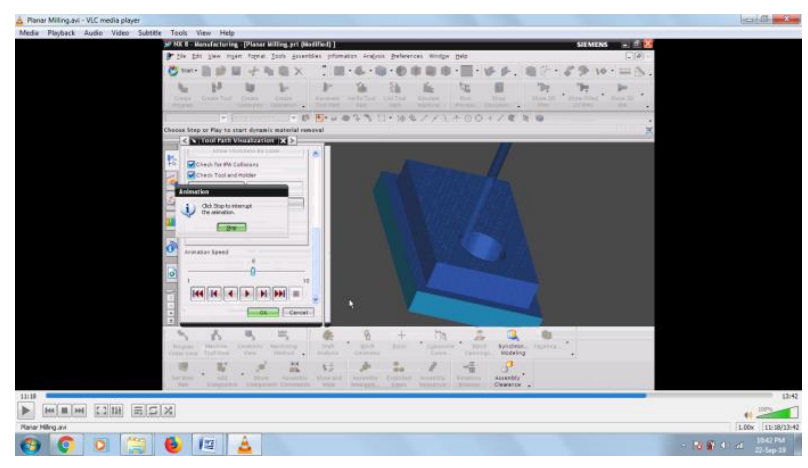

Fig. 1: Still captured from plain milling video clip

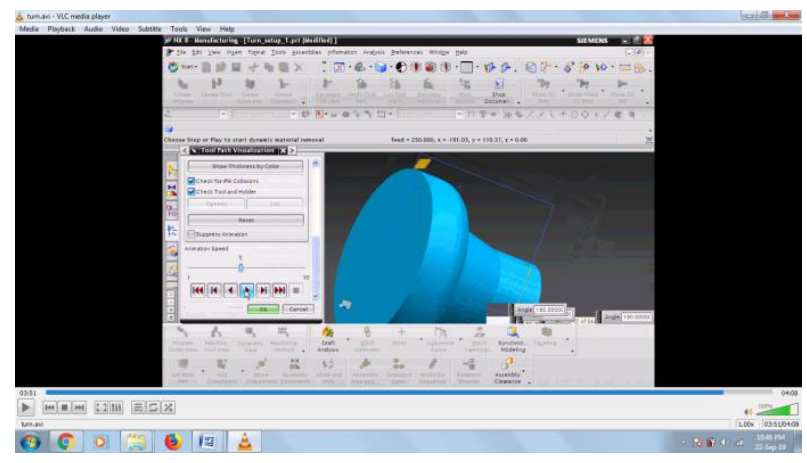

Fig. 2: Still captured from turning operation video clip.

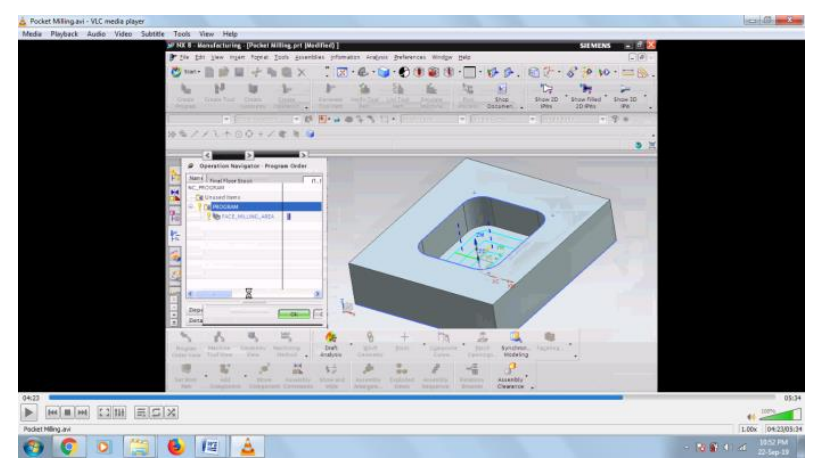

Fig. 3: Still captured showing tool path generation in pocket milling operation 


\section{Assessment}

Assessment was based on the rubric developed for the this course. Course outcomes are mapped with experiments. Assessment was based the performance indicators like right approach and logical sequence of steps, timely completion of the experiment, presentation and writing skills, report submission etc.

Table 1: Laboratory Assessment Rubric

\begin{tabular}{|c|c|c|c|c|}
\hline Criteria & Proficient $(<8$ to 10$)$ & Adequate $(<6$ to 8$)$ & Substandard $(<5$ to 6$)$ & Unacceptable( $(0$ to 5$)$ \\
\hline $\begin{array}{l}\text { Active } \\
\text { Participation } \\
(20 \%)\end{array}$ & $\begin{array}{l}\text { Student demonstrates an } \\
\text { accurate understanding of } \\
\text { the lab objectives and } \\
\text { concepts. The student can } \\
\text { correctly answer } \\
\text { questions and if } \\
\text { appropriate, can explain } \\
\text { concepts to fellow } \\
\text { classmates. Student is } \\
\text { eager to participate and } \\
\text { assists when needed }\end{array}$ & $\begin{array}{l}\text { Student arrives on time } \\
\text { to lab, but may be } \\
\text { unprepared. Answers to } \\
\text { questions are basic and } \\
\text { superficial suggesting } \\
\text { that concepts are not } \\
\text { fully grasped. }\end{array}$ & $\begin{array}{l}\text { Student tardiness or } \\
\text { unpreparedness makes } \\
\text { it impossible to fully } \\
\text { participate. If able to } \\
\text { participate, student } \\
\text { has difficulty } \\
\text { explaining key lab } \\
\text { concepts. }\end{array}$ & $\begin{array}{l}\text { Student was absent } \\
\text { from lab or did not } \\
\text { participate. There } \\
\text { was no attempt to } \\
\text { make prior } \\
\text { arrangements to } \\
\text { make up the lab. }\end{array}$ \\
\hline $\begin{array}{l}\text { Timely } \\
\text { completion } \\
\text { of } \\
\text { experiment } \\
(20 \%)\end{array}$ & $\begin{array}{l}\text { Students completes the } \\
\text { experiment before } \\
\text { stipulated time }\end{array}$ & $\begin{array}{l}\text { Students completes the } \\
\text { experiment on stipulated } \\
\text { time }\end{array}$ & $\begin{array}{l}\text { Student completes the } \\
\text { experiment but takes } \\
\text { more than stipulated } \\
\text { time }\end{array}$ & $\begin{array}{l}\text { Student could } \\
\text { complete the } \\
\text { experiment on } \\
\text { his/her own }\end{array}$ \\
\hline $\begin{array}{l}\text { Right } \\
\text { approach } \\
\text { and logical } \\
\text { sequence of } \\
\text { steps }(20 \%)\end{array}$ & $\begin{array}{l}\text { Student follows the right } \\
\text { approach and logical steps } \\
\text { to improve the quality of } \\
\text { the sketch, solid model } \\
\text { and tool path }\end{array}$ & $\begin{array}{l}\text { Student follows the right } \\
\text { approach and logical } \\
\text { steps with minor } \\
\text { mistakes to improve the } \\
\text { quality of the sketch, } \\
\text { solid model and tool } \\
\text { path }\end{array}$ & $\begin{array}{l}\text { Student fails to follow } \\
\text { the right approach and } \\
\text { logical steps which } \\
\text { results in poor quality } \\
\text { of the sketch, solid } \\
\text { model and tool path }\end{array}$ & $\begin{array}{l}\text { Student could } \\
\text { complete the } \\
\text { experiment on } \\
\text { his/her own }\end{array}$ \\
\hline $\begin{array}{l}\text { Writing/ } \\
\text { presentation } \\
\text { Skills }(20 \%)\end{array}$ & $\begin{array}{l}\text { All content points of } \\
\text { experiment are } \\
\text { systematically written and } \\
\text { presented. }\end{array}$ & $\begin{array}{l}61 \%-80 \% \text { content points } \\
\text { of experiment are } \\
\text { systematically written } \\
\text { and presented. }\end{array}$ & $\begin{array}{l}51 \%-60 \% \text { content } \\
\text { points of experiment } \\
\text { are systematically } \\
\text { written and presented. }\end{array}$ & $\begin{array}{l}\text { Below 50\% content } \\
\text { points of experiment } \\
\text { are systematically } \\
\text { written and } \\
\text { presented. }\end{array}$ \\
\hline $\begin{array}{l}\text { Report } \\
\text { Submission } \\
(20 \%)\end{array}$ & $\begin{array}{l}\text { Student demonstrates an } \\
\text { accurate understanding of } \\
\text { the lab objectives and } \\
\text { concepts. Questions are } \\
\text { answered completely and } \\
\text { correctly. Graphs are neat, } \\
\text { creative and include } \\
\text { complete titles and } \\
\text { accurate units. Errors, if } \\
\text { any are minimal }\end{array}$ & $\begin{array}{l}\text { Student has a basic } \\
\text { knowledge of content, } \\
\text { but may lack some } \\
\text { understanding of some } \\
\text { concepts. Questions are } \\
\text { answered fairly well } \\
\text { and/or graphs could have } \\
\text { been done more neatly, } \\
\text { accurately or with more } \\
\text { complete information. }\end{array}$ & $\begin{array}{l}\text { Student has problems } \\
\text { with both the graphs } \\
\text { and the answers. } \\
\text { Student appears to } \\
\text { have not fully grasped } \\
\text { the lab content and the } \\
\text { graph(s) possess } \\
\text { multiple errors. }\end{array}$ & $\begin{array}{l}\text { Student turns in lab } \\
\text { report late or the } \\
\text { report is so } \\
\text { incomplete and/or so } \\
\text { inaccurate that it is } \\
\text { unacceptable }\end{array}$ \\
\hline
\end{tabular}


Table 2: Marks Secured for the Experiments as per Rubric

\begin{tabular}{|c|c|c|c|c|c|c|c|c|c|c|c|}
\hline Expt NO & 01 & 02 & 03 & 04 & 05 & 06 & 07 & 08 & 09 & 10 & Total \\
\hline Marks (50) & & & & & & & & & & & \\
\hline
\end{tabular}

Average Marks = Total Marks/No of Experiments

Table 3: Form used to record marks Secured by the student as per rubric

\begin{tabular}{|c|c|c|c|c|c|c|c|c|c|c|}
\hline 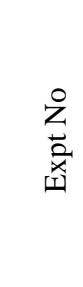 & Title of the Experiment & 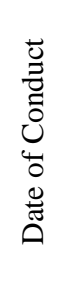 & 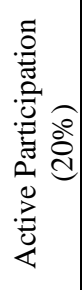 & 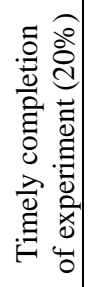 & 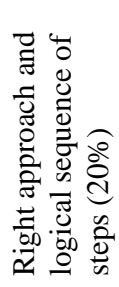 & 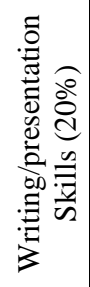 & 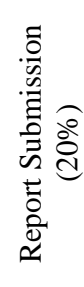 & 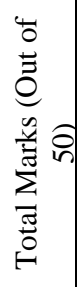 & 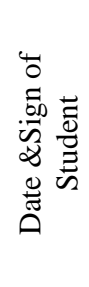 & 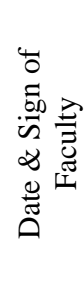 \\
\hline 1 & & & & & & & & & & \\
\hline 2 & & & & & & & & & & \\
\hline 3 & & & & & & & & & & \\
\hline 4 & & & & & & & & & & \\
\hline 5 & & & & & & & & & & \\
\hline 6 & & & & & & & & & & \\
\hline 7 & & & & & & & & & & \\
\hline 8 & & & & & & & & & & \\
\hline
\end{tabular}

Rubrics is used to improve performance of the Student by clearly showing them how their work is assessed and what is expected.

$>$ Students become better judges of the quality of their own work.

$>$ Students have more informative feedback about their strengths and areas in need of improvement.

$>$ Students become aware of the criteria to use in providing peer feedback.

$>$ Criteria are determined in specific terms.

$>$ Assessment is more objective and consistent.

$>$ Amount of time spent assessing student work is reduced.

$>$ Effectiveness of instruction is examined using multiple methods.

$>$ Progress is measured and documented against benchmarks. 
Table 4: Marks secured by students for first 4 experiments (before use of visual aids)
Average of marks secured by all the students for the first four experiments, before use of visual aids is 41.60 . The average of marks secured by all the students for last four experiments, after use of visual aids 46.80. This shows that students performance has been improved after use of visual aids.

\section{Conclusions}

The use of visual aids for teaching of skill based laboratory course has been discussed in this paper. Enhancement in the performance of the students was observed after use of visual aids. Use of visual aids also resulted in:

i) Less number of calls to the faculty from the students to solve their problems

ii) Students could complete the experiments in much lesser time than they used to earlier

Performance grades of the students improved.

\begin{tabular}{lllllll}
\hline 1822001 & 42 & 43 & 45 & 47 & 44.25 & \\
1822002 & 38 & 38 & 40 & 40 & 39.00 & \\
1822003 & 41 & 42 & 44 & 44 & 42.75 & References
\end{tabular}

$\begin{array}{llllll}1822004 & 37 & 38 & 38 & 39 & 38.00\end{array}$

$\begin{array}{llllll}1822005 & 40 & 42 & 44 & 44 & 42.50\end{array}$

$\begin{array}{llllll}1822005 & 42 & 42 & 44 & 45 & 43.25\end{array}$

$\begin{array}{llllll}1822006 & 40 & 42 & 44 & 44 & 42.50\end{array}$

$\begin{array}{llllll}1822007 & 38 & 40 & 42 & 42 & 40.50\end{array}$

Average of first 4 experiments of all students

41.60

[1] Richard M. Felder and Rebecca Brent, "Learning by doing", Chemical Engineering education (2003), 37(4), 282-282

[2] D. Kalyani and K. Rajasekaran, "Innovative teaching and learning", Journal of applied and advanced research (2018), 3(suppl.1), S25-S28.

[3] Ujjwala Patil et. al., "Activity based teaching learning: An experience", Journal of engineering education transformations, Special issue, eISSN 2394 1707

[4] P. C. Naga et. al., "Innovative methods of teaching learning", Journal of applied and advanced research (2018), 3(suppl. 1), S20-S22.

Table 5: Marks secured by students for last 4 experiments (after use of visual aids)

\begin{tabular}{llllll}
\hline $\begin{array}{l}\text { PRN of } \\
\text { Student }\end{array}$ & Expt.5 & $\begin{array}{l}\text { Expt } \\
6\end{array}$ & $\begin{array}{l}\text { Expt. } \\
7\end{array}$ & Expt.8 & Average \\
\hline 1822001 & 42 & 44 & 47 & 48 & 45.25 \\
1822002 & 47 & 45 & 47 & 48 & 46.75 \\
1822003 & 42 & 47 & 48 & 48 & 46.25 \\
1822004 & 46 & 47 & 48 & 48 & 47.25 \\
1822005 & 46 & 47 & 48 & 48 & 47.25 \\
1822005 & 47 & 47 & 47 & 48 & 47.25 \\
1822006 & 46 & 47 & 48 & 48 & 47.25 \\
1822007 & 46 & 47 & 48 & 48 & 47.25 \\
\hline \multicolumn{7}{c}{ Average of last 4 experiments of all students } & 46.80
\end{tabular}

[5] C. M. Khairnar, "Advanced pedagogy: Innovative methods of teaching and learning", International journal of information and education technology (2015), 5(11), 869-872.

[6] A. Nicolaides, "Innovative teaching and learning methodologies for higher education institutions", Educational research (2012), 3(8), 620-626. 